\title{
グラスゴーシティセンターの街路と街区の形成 \\ A STUDY OF THE GRID PLAN DEVELOPMENT IN GLASGOW CITY CENTER
}

\author{
今川朱美，布野修司** \\ Akemi T.IMAGAWA and Shuji FUNO
}

\begin{abstract}
In the eighteenth century, in Glasgow, the merchants who run trade business with colonial America proceeded the new town development. This new town was planned with the concept of "point-de-vue", and became known as "Merchant City". After this Merchant City development, the new town was extended to the west, and planned with the concept of grid plan by James Barry. After Barry's plan, the varieties of the new town developments were carried out, and consequently the industrial area north of Clyde River, Trade Town south side of the river, and the new town in Blythwood came into existence. Now the area to the north east of Merchant City is being developed as a residential area.

This paper aims to clarify difference of the concept in the grid planning process in so-called Glasgow New Town, particularly for thirty years since Merchant City had been planned at the end of the eighteenth century. The author proposes that this thirty year new town development can be divided into six phases, each of which were planned with different concepts. The main purpose of this study is to analyze these different concepts and the contexts which necessitated the different planning only for thirty years.
\end{abstract}

Keywords : $\quad$ Glasgow, Grid Plan, Merchant City, Point-de-vue, New Town グラスゴー、グリッドプラン、マーチャシトシティ、ポワン・ド・ヴュ、ニュータウン

\section{1 はじめに}

本稿は、グラスゴー1) のシティセンター2）を対象とし、マーチャ ントシティMerchant City ${ }^{3)}$ の発生 $\left(1712^{4}\right)$ から、1810年頃までの 開発過程を 5 つの時期に分類することによって、現シティセンターの 各地区の街路体系や街区構造の背景となる計画理念の相違点を明らか にすることを目的とする。また、開発の行われた時期のグラスゴーは 国際的に活発な経済活動を行っていた。アメリカとの貿易を通じ、物 品の流通だけではなく、都市形成の上にも影響を受けていることに着 目した。

18世紀末、タバコの貿易を営んでいた商人達によりポワン・ド・ヴュ point-de-vueという手法を用いてマーチャントシティ(第1 地区)が形

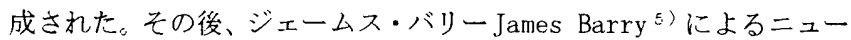
タウン(第 2 地区)、クライド川北岸の木綿工場地区(第 3 地区)、南岸 のトレイドタウンTrade Town (第 4 地区)、ブリスウッド Blythwood ニュータウン(第5 地区)が順次開発された(図 1)。

グラスゴーの都市形成に関してFrank. A. Walker ${ }^{\natural)}$ が、地図を用い て街路体系の発生をまとめている。都市史に関わるものとしては、ス コットランド都市史に関するPeter Reed ${ }^{7)}$ の研究がある。また、地 理学では、Andrew Gibb ${ }^{8)}$ 、Michael Pacione ${ }^{9)}$ の研究が代表的であ る。C.R. MackintoshやAlexander Greek Thompsonなどの著名な建築
家を輩出したこともあって、市内には多くの洗練された建築物が点在 している。Charles McKean ${ }^{10)}$ 、Thomas Markus ${ }^{11)}$ な゙゙多くの研究者が 論文や文献をまとめており、建築に関わる資料は豊富である。主要な 文献は全て収集し12)、参考文献に示している。しかし、いずれの研究 も概括的な観点からの研究であり、各地区の計画手法の差異を明らか にするのは本稿が初めてである。

本研究では、最新のシティーセンター測量地図10葉 $(1 / 2500)^{13)}$ を 用いた現地調査 ${ }^{14)}$ をもとに、都市成立当初の地図を分析し、それぞれ の街区形成の課程について考察を行った。本稿では、時期別、地区別 に街路体系と街区構成、特にグリッド状街区の計画手法と理念の違い に焦点を当てる。産業革命の時期、世界で有数の経済都市であったグ ラスゴーの当時の都市計画の変遷をたどることは、都市とその経済活 動の関倸を都市の形態に見いだすことができると考える。

ポワン・ド・ヴュという景観的に極めて興味深い手法や、その後の グリッドプランの多様性を再評価寸る上で、大きな意義を有している。

\section{2 シティセンターの地区区分}

グラスゴーは、大聖堂 (図 5 ) を中心とする典型的な中世都市として 発展してきたが、アメリカなど植民地との大西洋貿易 ${ }^{15)}$ が盛んになる と、18 世紀末から 19 世紀初頭にかけての 30 年余りの短期間に急速に

\footnotetext{
* 京都大学大学院工学研究科 大学院生・建築学修士: Graduate Student, Graduate School of Engineering, Global Environment Engineering, Kyoto University, M. Archi.

** 京都大学工学部生活空間学科 助教授・ 工博 Assoc. Prof., Department of Architecture and Environmental Design, Faculty of Engineering, Kyoto University, Dr. Eng.
} 


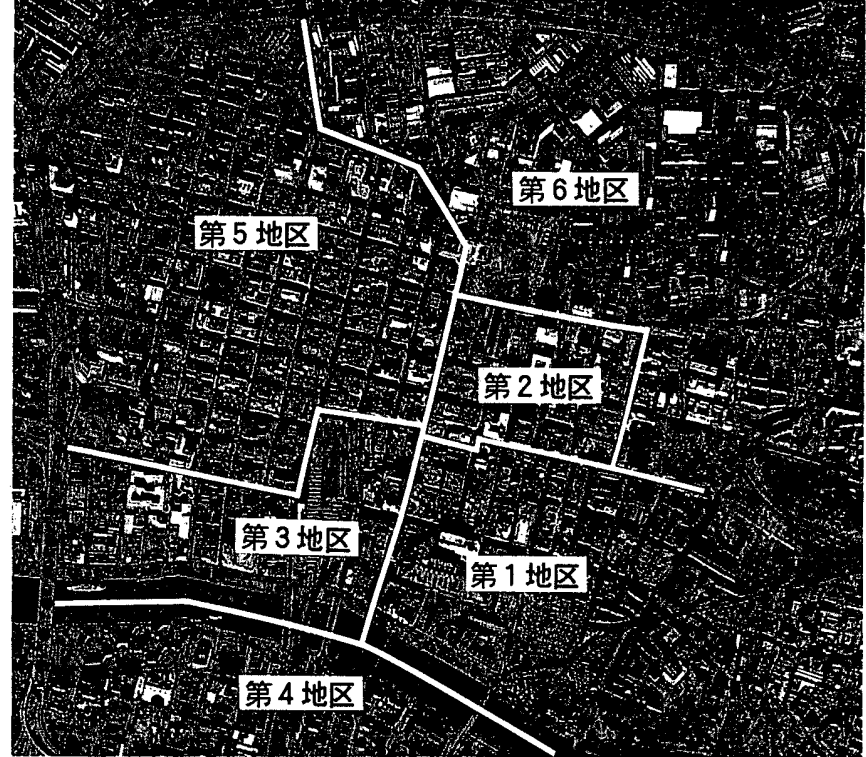

图 1 グラスゴーシティーセンターの航空写真、1994（出典 : 文献[16] pp.2）

産業都市としての形態を整える。グラスゴーの都市計画に関する既往 の研究は、この間の都市の発達を 2 期もしくは 3 期に分類している。 前期は貿易商人の街マーチャントシティの発達とその北部にバリーに よるニュータウンの開発、後期はマーチャントシティの西と南の ニュータウンの開発である ${ }^{16)}$ 。3 期に分類する場合 ${ }^{17}$ は後期の二ュー タウン計画を、川の南側の計画を 2 期目、北側を 3 期目としている。 現地調查によると、シティセンターは、その景観、すなわち街路幅、 建築群、用途などから6つの地区に分類される(図 1)。第 1 地区は マーチャントシティと呼ばれている地区も含み、その中心軸となるト ロングートTrongate・アーガイルストリートAgyle St. (連続した道 路であるが途中からら名称が変わる)は東西の道路であるが、そこから 北に延びる道は次のブロックで行き止まりとなる。通りの正面に建つ 建築物は、それぞれが特徴的であり、現在は美術館や病院など公共建 築として利用されいる。第 2 地区はマーチャントシティの北部に位置 する地区で、市役所とジョージ・スクエアGeorge Square (市役所前 広場) が核となったグリッド状街区が開発されている。第 3 地区は、 クライド川の北側一帯の短冊状の街区に倉庫や工場が建ち並ぶ地区で あるが、放置されて使われていない街区が目に付く。第 4 地区は川の 南側の造船工場や倉庫の地区で、近年に再開発計画が進められてい る。第 5 地区は、ブリスウッドと呼ばれていた丘陵地に、グリッド状 街区が開発されている。南北方向の傾斜に合わせて建物が段状に建 ち、他に例を見ない都市景観を作り出している。街区は基本的に東西 に少し長く、レーン lane と呼ばれる小径が街区を南北に 2 分割して いる。地形が平坦でないところでは、間口の狭いビルが建ち、商業地 区でもあり工夫が凝らされた比較的小規模な建築が多い。第 6 地区は 未利用地が多く、現在住宅開発が推進されている。この6つの性格の 異なる地区は、開発された時期毎にも分類が可能である（表 1 ）。

\section{3 ポワン・ド・ヴュの計画概念と手法}

3-1 ポワン・ド・ヴュ

ヴァージニアとの貿易在営んでいたダニエル・キャン゙ベルDaniel Campbe11 (1671-1753) は、トロングートの北側にあって、南に延びる ストックウェルストリートStockwell St. (現幅員60ft. ${ }^{18}$ ) ) の正面
に位置する広大な土地を購入し19〉、1712年にストックウェルストリー トからクライド川に架かる橋を眺めおろすことのできる位置にシャウ フィールド・マンションShawfield Mansion ${ }^{20)}$ (図 2, 図 3 ) を完成さ せた。このマンションはコレン・キャンベルColen Cambel1 121)(16761729)によってデザインされた。当時のエリート主義を象徴するパラ ディオ様式が採用され、グラスゴーにとって重要な都市軸の延長線上 に建つその邸宅を、街路上のどの地点からも望むことができるように し、ダニエル・キャンベルの社会的権力を誇示するものとなった。ポ ワン・ド・ヴュと呼ばれるその手法は、個人的な権力や社会的地位を 示すために建設された建築物を、丁型の交差点におくことにより、そ の建築物に視点が集まる様に街路を構成する街路計画手法である ${ }^{22}$ 。 丁型路では、通常のグリッドによる透視画法の効果が期待できず、そ の視線の先には邸宅がそびえ、景観の奥行きを切断することになる。 視線を集める建築が道路の延長上に位置し、道路が建築によって切断 されるこの手法によって、軸線の通らない閉ざされたグリッドプラン が誕生する事になった。

私邸のシャウフィールド・マンション以前には、キャンドレリーグ ストリート (40ft.) の北端に建つノースウエスト教会(図 3,1743 )にグ ラスゴーで最初のポワン・ド・㟔が用いられている。この手法が、都 市の内部に向けて用いられているのであれば、都市の管理、防衛、都 市民への権力の誇示が考えられる。が、シャウフィールド・マンショ ンは世界への玄関口であるクライド川に向かって建設されていること から、そのファサードは、世界に向けられていると考えられる。

\section{3-2 街路の形成}

17世紀中頃までグラスゴーには数本の街路と、街路を結ぶワインド wynd と呼ばれる小径が数多くあった。ブリッジダートBridgegate (50ft.) とトロンゲート(平均 $74 \mathrm{ft}$. ) も2本のワインド(12ft〜20ft.) によって結ばれていた。(図3)小路には小さな小屋が立ち並んでいた。

18 世紀に入り、他国との交易が盛んになと、荷物の運搬のためによ り広い道が必要となり、小径に代わって道幅のある道路が建設される。 1722-24 年には、トロングートとブリッジグートを結ぶキングスト リートKing St. (50ft.) がトロングートに直角に交差する街路パター ンのモデルとして建設さた。キングストリートに建設された牛肉、羊 肉、チーズやバターなどの市場は、イオニア式、ドリス式の玄関を通 り抜けると、広い中庭を取り囲む様に市場が計画されていた。他にも、 砂糖の倉庫やテネメントTenements ${ }^{23)}$ も建設された。トロンダートよ り北側には規模の大きい一戸建てが立ち並んでいたが、南側にはさら に重量感のある建造物が建ち並び、南の川にかけての都市形態を変容

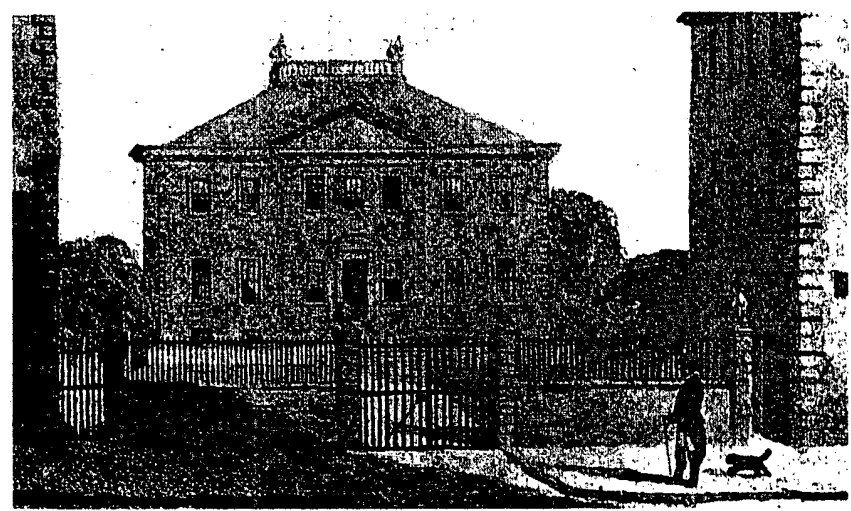

图2 シャウフィールド・マンション

The Shawfield Mansion (出典 : 文献[14] pp. 28) 
表 1 地区別分類一筧表

○泣南北の道路、日は東西の道路

\begin{tabular}{|c|c|c|c|c|c|c|c|c|}
\hline & 地区名称 & $\begin{array}{c}\text { 開發時期 } \\
\text { 開発者 } \\
\end{array}$ & 開発の要因 & $\begin{array}{l}1 \text { 街区の大きさ } \\
\text { 南北×東西 }=\mathrm{ft}^{2}\end{array}$ & 特 & 道 路 名 & $\begin{array}{l}\text { 計画又は } \\
\text { 建設年次 }\end{array}$ & $\begin{array}{c}\text { 道路幅 } \\
\text { (ft.) }\end{array}$ \\
\hline 1 & $\begin{array}{l}\text { マーチャント・ } \\
\text { シティー } \\
\text { Merchant City }\end{array}$ & $\begin{array}{l}18 \text { 世紀中頃 } \\
\text { 貿易商人 }\end{array}$ & $\begin{array}{l}\text { 貿易の発展 } \\
\text { 貿易商人のスディタ } \\
\text { の表現 }\end{array}$ & $\begin{array}{c}390 \sim 740 \times 123 \sim 285 \\
=47,920 \sim 151,800\end{array} \mid$ & $\begin{array}{l}\text { ポワン・ド・ヴュ } \\
\text { ダブル・ウッデン・コウム } \\
\text { (Doble wooden comb) } \\
\text { 渻蒾 (Comb Tooth) }\end{array}$ & $\begin{array}{l}\text { - King Street } \\
\text { - Virginia Street } \\
\text { Miller Street } \\
\text { Queen Street } \\
\text { - Buchanan Street } \\
\text { - Hutcheson Street } \\
\text { Glassford Street } \\
\text { - Wilson Street }\end{array}$ & $\begin{array}{l}1722-24 \\
1756 \\
1761 \\
1762 \\
1771 \\
1791 \\
1792 \\
1790-\end{array}$ & $\begin{array}{l}50 \\
40 \\
40 \\
60 \\
68 \\
40-60 \\
60 \\
70,40\end{array}$ \\
\hline 2 & $\begin{array}{l}\text { バリーによる } \\
\text { ニニータウン } \\
\text { Barry's New Town }\end{array}$ & $\begin{array}{l}1782 \text { 頃 } \\
\text { James Barry }\end{array}$ & $\begin{array}{l}\text { 貿易扗大に伴う都市の } \\
\text { 払大 }\end{array}$ & $\begin{array}{l}224 \times 236=56,864 \\
\begin{array}{c}\text { 計測街区: } \\
\text { City Chamber }\end{array}\end{array}$ & $\begin{array}{l}\text { 格子状街区 } \\
\text { 中央広場 } \\
\text { アメリカ植民都市との } \\
\text { 類似性 }\end{array}$ & $\begin{array}{l}\text { Virginia Street を延長 } \\
\text { Miller Street を延長 } \\
\text { Queen Street を延長 } \\
\text { - Buchanan Street } \\
\text { St. Vincent Street } \\
\text { - George Street } \\
\end{array}$ & $1782 \sim$ & $\begin{array}{l}60 \\
60 \\
60 \\
60 \\
53 \\
60\end{array}$ \\
\hline 3 & $\begin{array}{l}\text { クライド川北岸 } \\
\text { 工場地区 }\end{array}$ & 19 世紀初頭 & $\begin{array}{l}\text { 貿易商品生産の為の } \\
\text { 工場立地の必要 }\end{array}$ & $677 \times 205=138,800$ & 短冊状街区 & - Jamaica Street & 1771 & 75 \\
\hline 4 & $\begin{array}{l}\text { クライド川南側の } \\
\text { ニュータウン計画 }\end{array}$ & 1807 年頃 & 内陸部の住宅需要 & & & & & \\
\hline 5 & $\begin{array}{l}\text { ブリスウッド・ } \\
\text { ニュータウン } \\
\text { Blythwood } \\
\text { New Town }\end{array}$ & $\begin{array}{l}1807 \text { 年頃 } \\
1820 \text { 年に } \\
\text { 計画見直し }\end{array}$ & 内陸部の住宅需要 & $200 \times 250=50,000$ & $\begin{array}{l}\text { アメリカのグリッドブラン } \\
\text { との類似性 } \\
\text { エジンバラのニュータウン } \\
\text { 計画との関連 }\end{array}$ & $\begin{array}{l}\text { Sauchiehall Street } \\
\text { St. Vincent Street } \\
\text { West Geoge Street } \\
\text { West Regent Street } \\
\text { Bath Street } \\
\text { Blythwood Street } \\
\text { Bope Street 他 }\end{array}$ & $1807 \sim$ & $\begin{array}{l}70 \\
60 \\
60 \\
60 \\
60 \\
60 \\
60\end{array}$ \\
\hline 6 & 北東部開発地区 & 現在 & 開発計画中 & & & & & \\
\hline
\end{tabular}

させ、かつての中世都市やポワン・ド・ヴュの構成する町並みとは異 なる景観を作り出した。

3-3 特殊なボワン・ド・ヴュ

アメリカとのタバコや砂糖の貿易で富を得た人々は、経済状態の良 くない貴族から土地を購入し、土地は社会的地位を示寸と共に政治力 を持つようになった。また、多くの貿易商人は古典様式のタウン八ウ ス24）をたてるようになった。

ジョージ・ブキャナンG. Buchnan (1728-62) ${ }^{25)}$ は、シャウフィール ド・マンションの西側に土地を購入し 1756 年に古典様式の豪華な ヴァージニア・マンション(図 3) を建設した ${ }^{26)}$ 。また、20 m程奥まっ た邸宅への進入路として、アーガイルストリート側から西に 4 度傾い た（後にVirginia St.（12.5m) となる）アべニュー27)を建設した。 東隣のシャウフィールド・マンションの広大な裏庭がイングラムスト リートIngram St. (60ft.) に接して抢り、その道の直線部分に対し垂 直に引かれた敷地境界線に対し平行に邸宅を建設したと考えられる。 邸宅南面の玄関が正面になるように建設したアベニューは、イングラ ムストリートの直線部に対し垂直に位置することになった。後のバ リーのニュータウン計画でイングラムストリートは直線に改良された ため、バージニアストリートと正確な＼cjkstart字に関係しその 2 街路の方向 のずれが地図上で際立つことになった。

この引き込み型のポワン・ド・ヴュは、1例しかないが、経緯とし て非常に興味深い。通常、マンションは、街を監視するような位置に 建設されているのに対し、引きこもった邸宅は、街に対する主張を持 たないかに見えて、街全体の方向とわずかにずれを生じさせることに より、地図上で見ると非常に目を引く。

その後、ブキャナンは都市の発展のために自分の土地が重要な位置 にあることに気づいた為、私的な邸宅への進入路を公的な道とし、邸 宅を迁回して北側のイングラムストリートへと抜けられるようにし た。1841年には邸宅正面と西側を舗装し、イングラムストリートと続

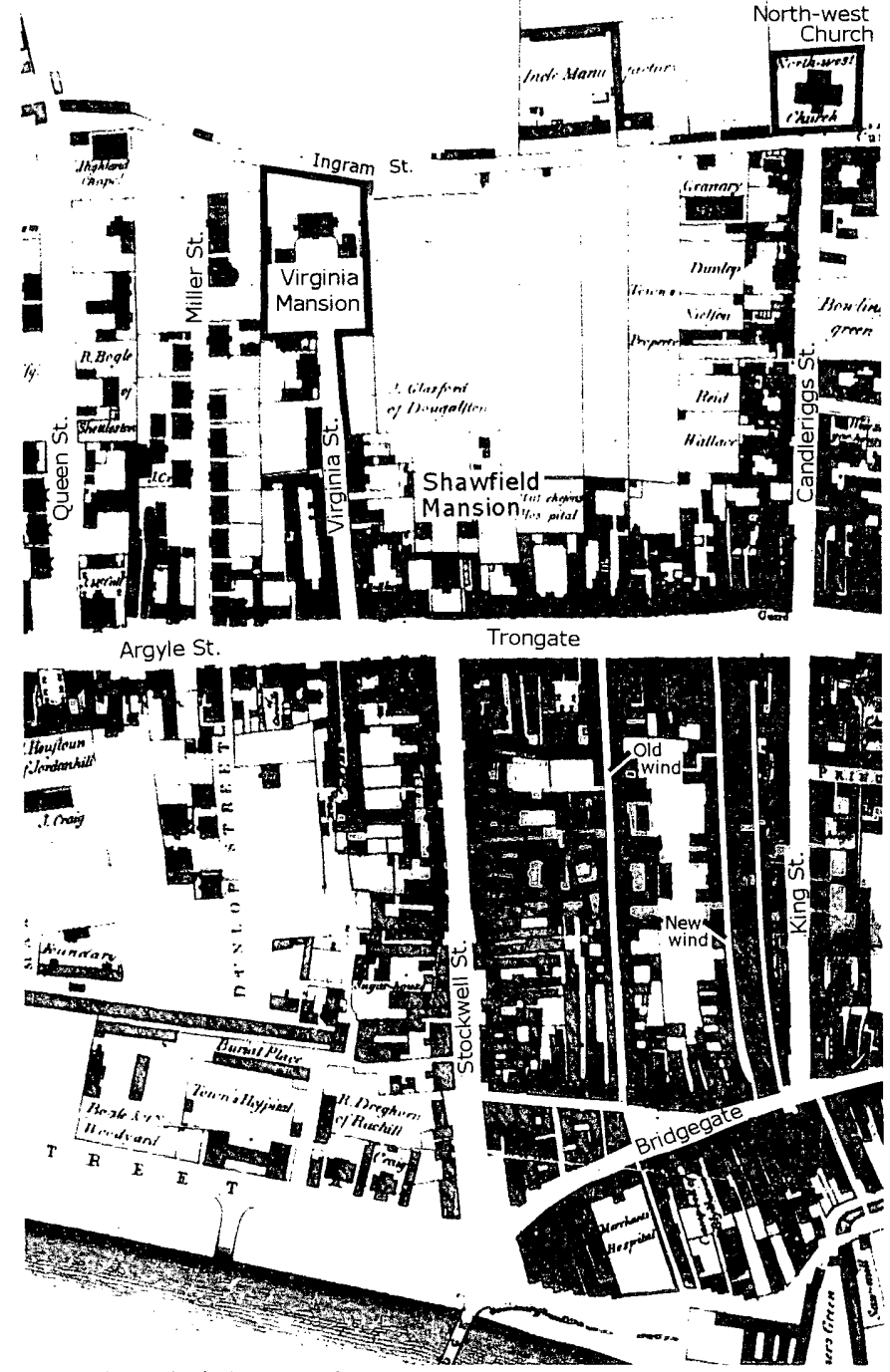

涊 3 グラスゴー都市図, 1778 年

Plan of the City of Glasgow, 1778, by Jhon McArthur (British Library) 


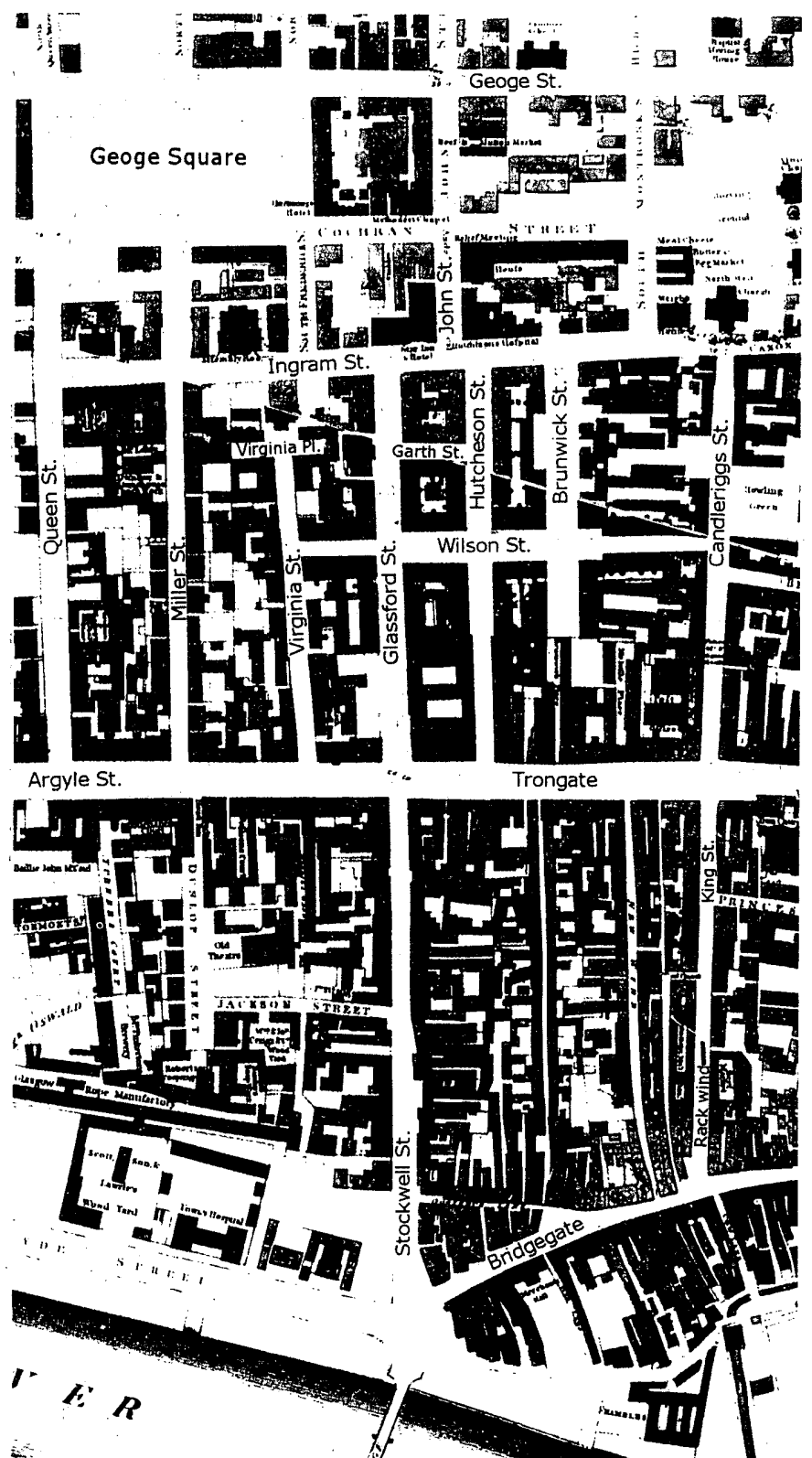

图 4 グラスゴー都市图, 1807 年、Map of the City of Glasgow and Suburbs, 1807 , by Peter Fleming (British Library)

くヴァージニアプレイスが建設され、ここに本来のポワン・ド・ヴュ の街路体系が出来た。そのL型のプレイスはトロングート・アーガイ ルストリートに対し方向をそろえており、ヴァージニアストリートと イングラムストリートには直交していない(図 4)。

3-4 ダブル・ウッデン・コウムの完成

ヴァージニアストリートに続いてミラーストリートMiller St (1761，40ft.)、クイーンストリートQueen St. (1762, 平均60ft.)、 ブキャナンストリートBuchanan St. (1771，68ft.)が建設さた。それ らの道は、トロングートとアーガイルストリートを軸として垂直に北 に延びる為、形態が櫛歯 (Comb Tooth)に見えることから、既に出来て いた南側に延びる街路を含めて、その街路体系はダブル・ウッデン・ コウムDouble wooden comb(背合わせの木櫛) 又はフィッシュボーン fishbone と呼ばれる ${ }^{28)}$ 。北に行くと邸宅に、南に行くとクライド川に よって行き止まりとなるこの街路体系は、先に述べたポワン・ド・ ヴュの作り出したものである。囲い込まれる様な印象を受けるこの構 成は、権力による圧力を感じる。実際、時の権力者であった貿易商人
達にとって、支配者として街の異変が監視できる位置に自邸を建設す ることは、単なるステイタスを示寸為ではなく、緩やかな丘上で前面 に建築物のない街路を正面にした 場所は、クライド川からアメリカ などに出発したり戻って来る自分の貿易船を眺めるのに都合の良い位 置であった。

3-5グリッド状街区の誕生

1790年にマーチャントシティに最後の大規模開発が行われた。ハッ チソンHutcheson ${ }^{29)}$ が自らの屋敷を取り壊し、トロンゲートからイン グラムストリートまでハッチソンストトリートHutcheson St. (40-60ft.) を開通させた (1791年)。バリーの計画したジョーンストリート (60ft.) と一直線に結ばれずに角に建つ建筑物につき当たり、ここにもポワ ン・ド・ヴュの手法が用いられる事になった(図 4)。

また、1792年にシャウフィールド・マンションを取り壊し、ハッチ ソンストリートの西側に平行して、旧市街とニュータウンを結ぶグラ スフォードストリートGlassford St. (60ft.) が造られた。この道路も イングラムストリートにつき当たり、北側に建つスコットランド銀行 （現在のイタリアンセンター）を際だたせるポワン・ド・ヴュの手法が 取られたことになる。この街路は南部へ向かってストックウエルスト リートからオールド・ブリッジ (現ビクトリア橋) 一と続く重要な交 通軸となった。そのハッチソンストリートとグラスフォードストリー トを結ぶガースストリートGarth St. (40ft.) は延長40m余りの短い通 りではあるが、西側の突き当たりにはロバート・アダムRobert Adam のトレイド・八ウス (1791-4)が建てられ、ポワン・ド・ヴュが生かさ れている。

個人開発業者のロバート・スミスは、購入したハッチソンストリー ト周辺の土地の開発を始めた。売却の条件としてハッチソンストリー トと平行する道路(現ブランスヴィックストリートBrunwick St. ) と、 ハッチソンストリートとキャンドレリグスストリートを結ぶ通り(現 ウィルソンストリートWilson St. ) を配置することが約束されており、

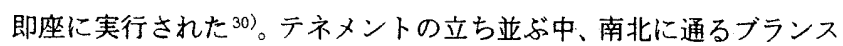
ウイック・ストリート (70ft. ) には、突き当たるイングラムストリート にポワン・ド・ヴュとなる視点の行き止まりにふさわしいものがな かった。一方、東西に伸びるウィルソンストリートはこの地区で最も 幅員の広い街路となり、新市街で最も優れたテネメントが立ち並んで いた。それ故、通り上に焦点があり、道路延長のうち中程の道幅を広 く(70ft.)、グラスフォードストリートから西端のヴァージニアスト リートまで、ブランスウィックストリートの交差点を東に越えたとこ ろより東側の道を狭く(40ft.) するといった工夫がなされていた。う した道路の建設が南北に長い街区を分割し、グリッド状街区と化した のである。これらの計画注、1804年に発行された,デンホレムの地図 31)によって見ることができる。

4 バリーのグリッド状街区

4-1.1782-1807の地図の分析

都市の应大に伴い、バリーがニュータウンの計画案を出したが、正 確なオリジナルプランは知られていない。ロスの地図 ${ }^{32)}(1773)$ とコー リーの地図 ${ }^{33)}(1776)$ にはそれを示寸ものが見受けられないので、その 計画はそれ以降の計画であったと推測される。1778年に出版された、 初めてグラスゴーの全体計画が描き込まれたとされるマッカーサーの 地図 ${ }^{34)}$ には、ブキャナンストリ゙ートと現在のセント・エノック・スク 


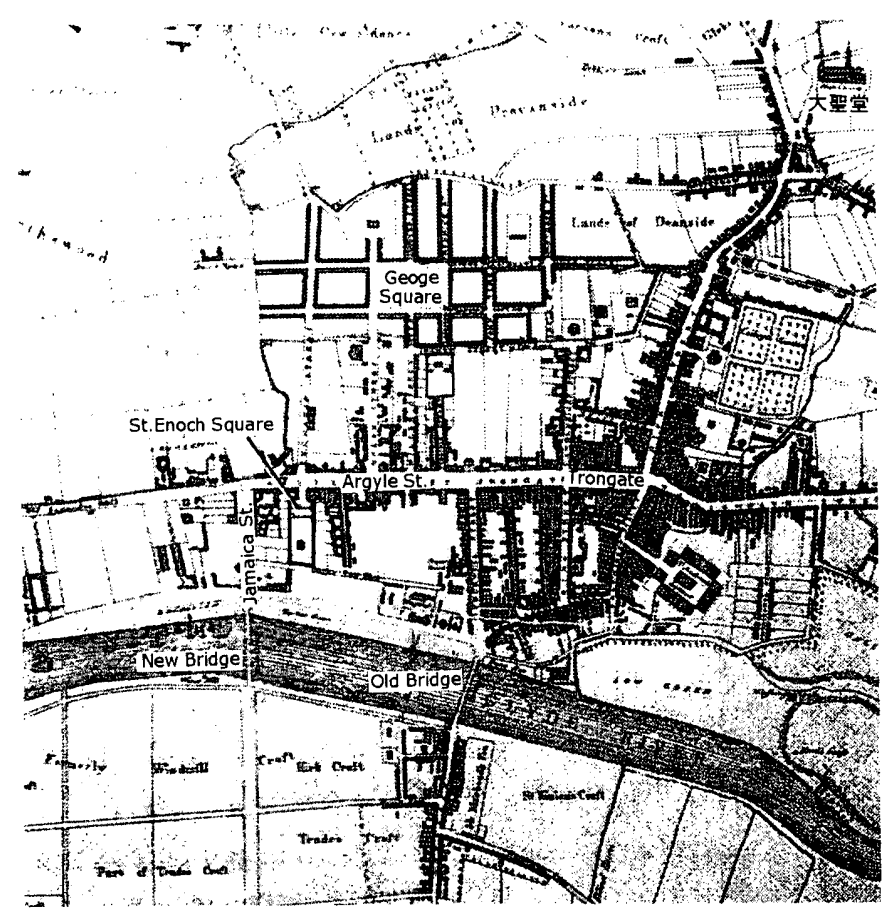

図 5 グラスゴー都市図，1782 年、Plan of the City of Glasgow， Gorbells Caltoun and Environs, 1782, from survey by James Barrie. Strathclyde Regional Archives (出典 : 文献 [18] pp. 30)

エアSt. Enoch Square (40ft.) となる空間が一直線に関係が提案され ているが、バリーの計画には見られない。

しかし，その 4 年後の 1782 年にマッカーサーの地図がバリーに よって改訂され35)、その中にはニュータウン 計画案が描き込まれて いる（Fig. 5)。地図には、イングラム・ストリートの北部に南北に 6 本、東西に 2 本の道路を計画し、明確な区画を示しグリッド状に街路 が構成されている。6本の南北軸の内 4 本は、西側から既存の主要道 路であるブキャナン、クイーン、ミラー、ヴァージニア・ストリート を延長する形で計画されていて、いずれの道も $60 \mathrm{ft}$. で計画されてい る。一番西のブキャナンストリートのみ東に傾いているが、これは計 画当初、セント・エノック・スクエアからカセイドロストリート上に ある交差点を結ぼうとしたと地図上では推測される。しかし、建設さ れたブキャナンストリートは、セント・エノック・スクエアをアーガ イルストリートと垂直に結び、真っ直ぐ北へ建設されている。

4-2 バリーのニュータウン計画

バリーはマーチャントシティーに既に存在する街路を延長し、幾何 学的な街路体型に計画すれ社、中世の都市パターンとうまく共存でき る可能性があると考えたと思われる。バリーのニュータウン注それま でのマーチャントシティに比べ非常に開放的であった。マーチャント シティは、ポワン・ド・ヴュによるT字路の街路構成が多く、街路は 交差点で行き止まりとなり閉鎖的であったが、バリーは道路軸を延長 することによって行き止まりのない街を提案している。貿易を営む 人々が海外で、グリッド状の街区で構成される都市を見聞きし、グラ スゴーの都市構造にも規律を求めた可能性もある。

ニュータウンには $2 つ の$ 街区をオープンスペースとするジョージ・ スクエアGeorge Square(図5)が描かれている。共用空間としての ジョージ・スクエアは、現在、重要な公共空間である市役所前広場と して利用されている。この様な空間は、アメリカでもいくつかの例を 見ることが出来る。1637年頃に建設されたニューイングランドに、簡
単なグリッドプランの中央に広場すなわち共用空間が採られている。 市場や祭りに利用された共用空間は、計画された都市の全面積の 9 分 の 1 を占めて抒り、広場としての役割を果たしていた ${ }^{36) 。 ハ ゙ リ ー か ゙ こ ~}$ の事例を参考にした可能性はある。

しかし、この計画がなされた当時はまだマンションの建設を目的と した開発が広く押し進められていており、ポワン・ド・ヴュの街路体 系の方が優勢であったと推測される。

バリーのニュータウンの様に、既にある街路体系を改良し新しい可 能性に挑戦する姿勢は、グラスゴーの社会構造の変化を反映していた と考えられる。18世紀の終わりに発足したグラスゴー市政は、徐々に 事業などを実現させる権力を持ち始めていた。それまでは貿易商人達 が権力者であり、都市開発も彼等の思いのままに進められ、都市形成 が進められていた。しかし、富とそれに付随した特権は、中産階級へ と移行し、貿易商人達の優位な立場は完全に押さえつけられることは なかったにせよ、絶対的な支配力は失った。

\section{5 クライド川北岸の短冊状街区}

貿易産業が著しく発展するにつれて、特に植民地から持ち帰った綿 花を木綿製品にする為の施設が必要となる。木綿の生産過程において 大量の水を必要とするため、必然的に工場は川の近くに建設されるこ とになった。

都市は拡大し、西側の境界線と呼ばれていた小川を超えて、ジャマ イカストリート(1751) と結び付き続いていった。1771年にこの道路の 延長上にニューブリッジ（現グラスゴー橋）が完成しグラスゴーの重 要な南北軸が誕生した。その、西側一帯が木綿製品の生産工場となっ た。施設建設の際、より多くの施設に平等に川の水を取り入れようと 川に向かって垂直に区画が整備された(図6)。また、こうすることに よって、工場から倉庫そして船へと商品を運搬する手間が省け、極め て合理的な土地利用となった。

公的には地区計画などがなされていなかったにもかかわらず、規律 ある短冊状の街区に構成されたのは、土地を売却する際同じ様な条件 の区画にしておけ代問題が起こりにくい為であったと考えられる。ま た、不定形の土地よりも区画された土地の方が、建築も簡単に建設で きる。また、短時間の間に、施設の建設を行うのにも有効であったと 思われる。

その後この地区は時代の波に乗って木綿工場から造船工場などに用 途が変わり、グラスゴーから起こった産業革命の一端を担った。

\section{6 ブリスウッド・ニュータウンのグリッド状街区}

\section{6-1 グリッド状街区の桩大}

市街内部の都市空間の街区形成が進むにつれて、都市は次第にその 周边部へと拡大し、バリーのニュータウンの街路を、西側の郊外一拡 大寸る方法が取られた。1804 年に発行されたデンホルムの地図まで は、新しい街路形態が見受けられない。その後発行された1806年の地 図はデンホルムの地図を参考に制作したものと考えられている ${ }^{37)}$ 。次 に発行されたフレミングの地図 ${ }^{38}$ (図6)には、グリッド状の街区が現 れている。この計画は、ブリスウッドの丘に覆い被さるように計画が なされたため、ブリスウッド・ニュータウンと呼ばれる。

土地分割をするのにも均一な方法であり、行き止まりや曲がりく 放った街路がなく明解であること、急速な都市の発展に対しても対応 
することができるという利点がグリッドプランの採用理由である。 最初のブリスウッド・ニュータウンの計画では、規律あるグリッド 状の街路の中でゴードンストリートGordon St. が斜行しているのが 目に付く。ウオーカーは、既に一部建設済みのゴードンストリートが 斜行しており、その延長であるためと指摘しているが゙9，地形図と比 較してみると、ゴードン・ストリートの北側に丘が位置しており、川 と平行して等高線と道路が伸びていることから、地形に沿った計画で あったと考えた方が素直である。

\section{6-2アメリカのグリッド状街区との関係}

もともとアメリカの都市の大半は、投機目的にヨーロッパ人達に よって計画された40)。土地売却による予算の獲得をねらう政府の思惑 と土地を求める移住者達の妥協として法律の制定が試みられた。

グラスゴーと関倸の梁いヴァージニアで 1662 年に、アメリカで最 初の規定に従っでグリッドプランが武みられている ${ }^{41}$ 。時期的にグラ スゴーの貿易商人達がグリッドプランの利点を参考にした可能性は大 きい。その後各地で植民都市建設が進み、ついに1785年に土地条例 が執行された ${ }^{42)}$ 。グリッドを使用する利点は、土地の調査、分割が簡 単なシステムであるため、土地投機そして土地区画を迅速に行える。 また、政府にとって記録をとりまとめやすく、人口調査や徽税を容易 にし、広い範囲に渡って植民者達の管理がしや寸い。グリッドという 手法は、新しい居住地区を開発する最も単純な手法であった ${ }^{43}$ 。

このようなグリッドプランによる直線的な計画手法は、地形的特徵 を無視しているが、未開発な荒野で土地売却を行う上では非常に有効
的な手段であり、土地境界に関連した争いを軽減するという意味でも、 効果的な手法であった。

アメリカとはタバコの専売、砂糖や木綿製品の貿易を通じ、密接に 関わって抢り、そもそも、北アメリカを中心とした植民地を開拓した スコットランド人が、その開発の手法をグラスゴーで忘用した可能性 は十分あると考えられる ${ }^{44)}$

6-3 エジンバラのニュータウンとの関係

エジンバラのニュータウンはジェームス・チェリングJames Craig (1744-95)によって 1766 年から67 年に計画された(図 7)。エジンバ ラも傾斜地に計画されており、地形も、社会経済的な状況もグラス ゴーと類似していた。

実際、グラスゴーの 2 度目のニュータウン計画であるブリスウッ ド・ニュータウンは明らかにエジンバラを参考にしていると言われて いる ${ }^{45)}$ 。街区の特徵から見ると、エジンバラの地形は南から北に向 かって高くなっている為、1区画の大きさは南北に短い。この方法を 用いると、東西の道路軸が水平に直線で続くのに対し、南北の街区は 短い間隔で上昇するため、丘であることを強く感じさせる。

1 街区内の南北端での高低差があり、建築物を建てる際、階高が階 段状になるため、少しでも緩和寸る方法として、ブロックを南北に 2 分割し、長い短冊状のブロックの間にレー゙ン laneと呼ばれるサービス 路を設けた。エジンバラは 1 つの街区が大きいため、街区の内側には レーンから進入する小さな住宅が建っており、2 重構造になっていた。 これは、現在のニュータウン計画にも通用する計画であり、スーパー

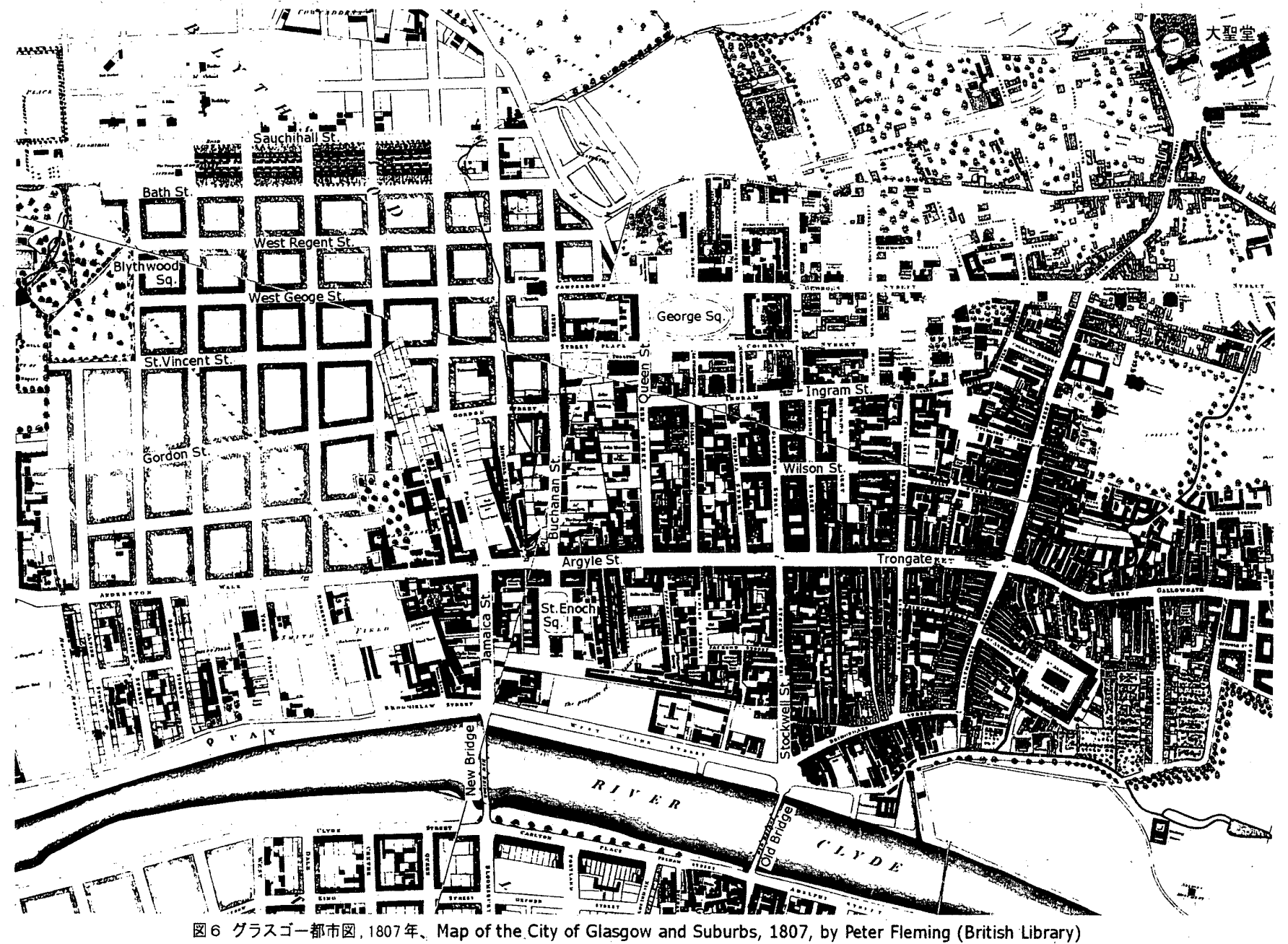




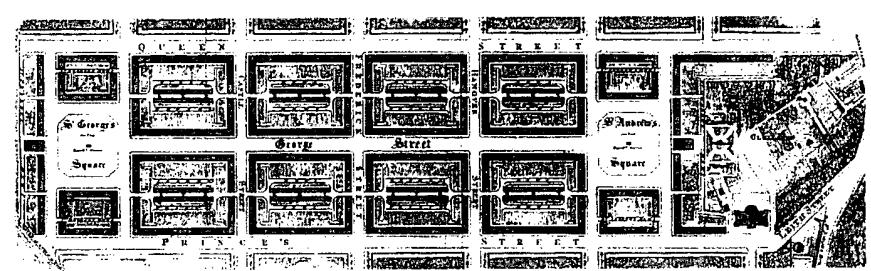

図7エジンバラ都市図、1767年、Plan of the new streets and squares intended for the City of Edinburgh, 1767, by James Chaig's（出典: 文献 [19] pp. 45)

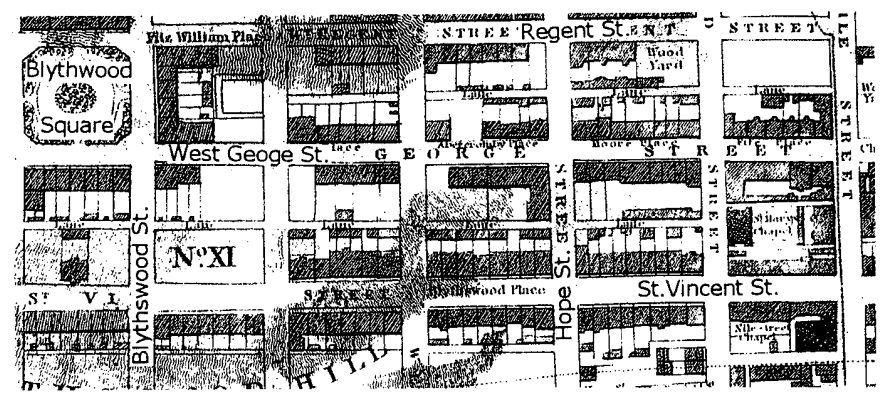

图 8 グラスゴー都市图，1828 年、Plan of the City of Glasgow and its Environs， 1828, (British Libraries)

ブロック内にループ状の生活道路があると考えると理解しや寸い。但 し住宅性生活道路に対し、背中合わせになっており、裹庭が設けられ ている。

グラスゴーのブリスウッド・ニュータウンの街区はエジンバラの 4 分の $1(250 \times 200 \mathrm{ft}$. $)$ で計画されている。これは、建物が同じ大きさ で計画されていたとして、背中合わせになるテネメントを北と南に 1 棟ずつにしたため、内側の住宅が必要なく、結果として街区の大きさ が 4 分の 1 となったと考えられる。レーンの幅員は 5 〜 $5.6 \mathrm{~m}$ (16 $18 \mathrm{ft}$. ) 前後であり、中世のグラスゴーにあったワインドと同じ性格の ものと思われる。通過交通の少ない小路によって、表通りから目に付 くことなくゴミの収集等が行われており、都市景観にも大きく貢献し ている ${ }^{46)}$ 。

この 2 点の共通点からグラスゴーはエジンバラの都市計画に影響を 強く受けたと論じられている。しかし、街区の性格は異なっているた め、全くのコピーではない。

\section{6-4グリッド状街区の起伏のある地形への展開}

グラスゴーでは、グリッド・プランが坂のある地区に適用されてい るが、地図上では気が付きにくい。しかし実際は、平面的に南北及び 東西へ広がりを見せる単純な透視画的なものではなく、傾斜に会わせ て街区毎に建築物も高低差を見せ、焦点も地形に合わせて移動する、 非常に特徵のある景観を形成している。

起伏上のグリッド状街区として美しい例の 1 つは、ジョージ・スク エアの南側からまっすぐ西のブリスウッド・ニュータウンに伸びるセ ントビンセントストリートSt.Vincent St.の北側の一帯である。そ こでは、ブリスウッドの丘の穏やかな斜面によって、2 階から 3 階建 てのテラスハウスが階段状のスカイラインを描いている。規則的なグ リッド状街区と、類似したジョージアン様式のファサード、連続性の ある肌色の砂岩で作られた建築は、一貫性のある景観をもたらしてい る。丘の上には居住地区にあるオープンスペースとしてブリスウッ ド・スクエア(図6)がつくられた。こうした視線の広がりを街の中に 設ける方法は、ポワン・ド・ヴュにこだわってきたグラスゴーの景観 に対寸る新しい智恵であろう。また、丘の北側にセントビンセントス
トリートと平行して東西に通るサキホールストリートSauchiehall St. はかつて曲線を描いていたが、道幅を広くし、直線道路となる様に矯 正し、通り沿いには洗練されたテラスをもつ建物が建てられた。

実測してみると、1 区画は扔扔よそ $200 \mathrm{ft} \times 250 \mathrm{ft}$.上なっている。 店舗及び住宅の一軒あたりの間口が約 $30 \mathrm{ft}$.であり、8軒で $250 \mathrm{ft}$. 程 になる。しかし、実際は、勾配の関係上、街区の大きさにはばらつき があり、例えばバースストリートに沿って、ブキャナンストリートか ら西に向かって、東西の街区の長さは $226 \mathrm{ft} ., 246 \mathrm{ft} ., 283 \mathrm{ft}$. , $275 \mathrm{ft} ., 254 \mathrm{ft} ., 246 \mathrm{ft}, 246 \mathrm{ft} ., 246 \mathrm{ft}, 287 \mathrm{ft}$ となっている。この ばらつきは、地盤の勾配と関係があると思われる。

道路幅はいずれも $60 \mathrm{ft}$.となっているが、これは街区内に建つ建築 物の高さと関係があると思われる。マーチャントシティでは、建物高 さが $40 \mathrm{ft}$. 程の邸宅の立ち並び $40 \mathrm{ft}$. の街路幅が主に採用されていた のに対し、ここでは大半が 4 から 5 階建てのテネメントが建ち、階高 が約 $4.5 \mathrm{~m}$ として 4 階で $18 \mathrm{~m}$ (60ft. )、5階建ての場合も、1 層分は 全面にドライエリアを設けて地下階とすることが多いため、建物高さ は 4 階の場合と同じく約 $60 \mathrm{ft}$. となる。また、建物の高さと道路幅員 は同じく $60 \mathrm{ft}$. 程であり、建造物の高さに対し圧迫感を感じない。但 し、ドライエリアを設けている建築物の全面道之の有効幅は $60 \mathrm{ft}$.に 足りないこともあるが、建築壁面から道路を挟んで対面の建築壁面ま での間は $60 \mathrm{ft}$. 以上となっている。後世になってから、ドライエリア の部分に硝子ブロックの床を作り、歩道として使用できるように改造 した籄所（ブキャナンストリート等）もあるが、ドライエリアを景観 と、地下店埔へのアクセスのために保存している道路もある。

ブリスウッド・ニュータウンは整然としたグリッド状街区が起伏の ある地形上に計画されたため、魅力的な景観を形成した。その幾何学 的なグリッド状街区は、起伏によって1街区の大きさを微妙に変化さ せており、同じ幅員をもつ道路もそれぞれ様子を違えていることが、 街区毎、道路毎の表情を少しずつ違えることになり、豊かな都市空間 を作り出している。

\section{7 結論}

グラスゴーシティーセンターの発展過程は 6 つの時期に分類でき、 それぞれ地区毎に以下のようなの発展をみせた。

第 1 地区、マーチャントシティーでの焦点となる建築を道路の行き 止まりに建設する「ポワン・ド・ヴュ」の手法は、ランドマークとな る建築物がほぼ道路ごとにあるため都市景観に表情を与えている。ま た、この手法が教会など公共建築ではなく、個人の邸宅に用いられた ことは非常に珍しく、興味深い。公共建築で有れば、その権力を表現 しつつ、町を閉ざし管理をするためにも合理的な構成といえるが、本 来プライベート性の高い邸宅を、重厚な門と塀で囲まずに、建物その ものを人の目に付くように配するというのは、田園地域での権力者の 趣向を都市部で再現したようにも考えられる。急激に経済成長をとげ た都市と一部の都市民の生み出した様式であるといえる。

第 2 地区のバリーのニュータウン及び第 5 地区のブリスウッド・ ニュータウンはいずれもグリッド状街区を持つ。貿易が盛んに行われ、 都市経済活動が非常に盛んであった時期のバリーのニュータウンは、 中央行政地区としての役目を果た寸ことを目的とした都市構成となっ ている。その 25 年程後に、成長した都市を支える中産階級以上の都市 民を対象とした、住宅・業務地区として計画されたブリスウッド・ 
ニュータウンは、生活への配慮としてレーンを用いた街区となってい る。グリッドを導いた時代的、社会的背景が街区形態を変え、ついて は都市景観にも影響している。

都市拡大の勢いに乗って第 4 地区の開発が押し進められようとした が、街区及び街路構成はブリスウッドニュータウンに類似しているも のの、地形の違いから壮大な景観が生まれず、単純なグリッドとなっ てしまっている。結果、街路条件としては望ましくない斜面地に広が る街区の方が人々に望まれている。

独特の発展を見せた川の北岸の産業地帯(第 3 地区) は、産業の合理 性が街区を形成した。合理性を求めたグリッドプランも、目的によっ て街区の大きさなどに違いが生まれる。

グラスゴーの街は、ジョージアン・タウンと分類されているが、グ ラスゴーの都市景観などをひとまとめにして分類することは不可能で ある。グラスゴーに現存するグリッドプランは、決して単調で画一的 なものではなく、街区規模、道路幅、等多様な工夫によって多様な景 観を作り出す可能性を持っている。

\section{註}

1）グラスゴーはケルト語の「緑の人」を意味する更葉が語源だといわれている。ローマ時 代にはエジンバラとグラスゴーを結ぶ要衙であったが、1178年にウィリアム王の自治が彗め られ街として哭達した。河口港としての恵まれた条件が貿易の街として栄え、皮革、衣服、銭 冶そして、木造船の生産も行っていた。19世紀には産業革命発祥の都市として、造船などの 重工業を中心として都市としての発達をとけ゚、今世紀にいたるまでには、大英帝国における、 ロンドンに次ぐ第二の工業都市してその繁栄を迎えた。しかし、100万人都市に成長したグラ スゴーも、第二次大戦後のイギリスの大不况、またグラスゴーの箦栄ささえた造船の票要低 下による重工業の衰退などによる経济状態の悪化などからくる近年の人口成少は激しく、失 業率も全国平均をおおきく上回る状態が長く䌇いている 1990 年にECより、ヨーロッパの文 化都市に指定され、現在は、1999年に向けての「UK City of Architecture and Design 1999」に英国のアート・カウンシルの選考により指定され、巨大ショッピングセンターの建 設をはじめとする数々のプロジェクトが 1999年に向けて進行中である。

2) グラスゴー市都市計画課によるシティセンターの地城区分は、自動車専用高速道路のM 8 より南西で、大聖堂を北東端に含み、クライド川より北の地城。(Fig. 1)地域内に現在開発 中の第 6 地区も含まれるが、今回の研究とは対象時期が違らため、研究对象外とした。

3) グラスジー市都市計画锞のマーチャントシティの地区区分は、北は George St. 、南は Trongate、東はHigh St. 、西はQueen St. に囲まれた地域となっている。

4) 通常 1560 年から 1800 年が、マーチャントシティー建設の時期とされているが、本論て はShawf iield Mantionの建設が重要な意味を持つため、それから後に着目している。

5) James BarryまたはBarrie。1734年に測量士としてグラスゴーのマーチャントシティの 邸宅の測量のために来た。1759年に街の有力者たちが報酬を扎って港や街路計画を依頼し、 その後もカウンシルや有力者達の依頼に応え、ヴーージニアストリートをイングラムストリー トに開通させたのもバリーであった。(D. Murray, Early Burgh Organization in Scotland, 1924,pp. 122 他、より)

6) 文献[17] [18][19]、グラスゴーの建察と都市史の研究書を多く執筆しており、特に街路 体系の発生についてまとめている論文がこの 3 冊に掲載されている。

7 ) 文献[17], [19]pp79-90、グラスゴーの都市史に関する論文が複数掲载されている。

8) 文献 $[5]$

9) 文献 [15]

10) 文献 $[12]$

11) 文献 [18]

12）都市史の大学関係の研究者、グラスゴー市の都市計画課の研究者の協力を得て、盗料の 收集を行い本稿に必要な文献、盗料を入手した。(Prof. Frank A. Talkerの御教示による) 13)Planning Dept., City of Glasgow District Council, Drawing on Glasgow $1 / 2500$. 10 葉 $(2,5,6,7,8,9,10,11,12,13), 1992$

14) 調查は、1995 年 5 月〜 1996 年 12 月の Postgraduate School, Mackintosh School of Architecture, University of Glasgow に留学期間中及び 1997 年 5 月 19 日〜 6月 7 日に 行った。

15）ヴァージニア，カリブ諸島，ニューインダランド等の植民地からタバコや砂糖、少し達 れて、木綿製品の貿易が盛んに行われていた。

16) Adans I.Hによる文献[6]での分類。

17) F. A. Walkerkよる分類。

18）1997年5月19日〜 6月7日の現地調査にて測量。以後、道路名と共に寸法が妻示された 場合は、調査による計測数値とする。

19) 文献[17], pp24

20) 文献[5]，pp. 50-51、文献[11]，pp. 62、文献[14]，pp. 28-29、文献[5]で完成年度が 1712 年となっているが、1711年が正しいと考えられる。

21) Colen Cambel11はShawfield Mansionをデザインするまでは茾萝士であった。英国で最 初のパラディオ建策を設計した建策家である。

22）文献 [19]，pp. 59

23） 4 階〜 5 階建の英国式の集合住宅で、ダラスゴーが発样の地と离われている。階段の左
右に1家族の住める住戸があり、階にようて住む人の身分が决まっていて地上に近いはと地 位の高い市民が住んでいた。地上階は、店舖なと営業施砓になっていることが多い。また、肌 色やビンクの砂岩造のテネメントが、グラスゴーの統一感ある景観を生み出している。 24） $2 \sim 3$ 階建の裹庭付き連続住宅。テラスの有無によりテラスハウスとは区別される。 25）有力なバージニアとの貿易商人の子棌。

26）文苚により、Virginia St.の出来た年に関する㲅㦻にばらつきがあり、F.A. Walkerは 1755 年と明婄している。しかし、個人的な郳宅一の通路として出来た道であり、邸毛の完成 と同時期に出来たと考えるのが自然である。

27)都市建案史教諭のDr. James Macaulay (Mack intosh School of Architeuture)のご教示 によると、田舎では大邸宅前通りを指す。期宅は南を正面にするため、特に南北の街路をす ベニューと呼ぶ。

28) J. McUre, が、「A View of the City of Glasgow」 Glasgow, 1736, pp.133で、マー チャントシティの街路体系をfishboneもしくはdouble wooden conbと説明している。

29）并護士一族のハッチソンは、自らの財座を投じて、ダラスゴーに頁献した為、ハッチソ ン・パトロンと乎ばれていた。

30) 文献 $[17]$, pp. 33

31）F. A. Walkerはいずれの論文でも McArthurの地图として紹介しているがＪ.Denholm の作成した地図であり、下地もMcArthurの測量地図を使用していないことが明らかになって いる。

32）Charles Rossの地図は、大聖堂からGorbels、Calton か⿰ら Proonielaw示示い、主要道 路名の記入された測量地図。(グラスゴー大学蔵)

33) Richard Collieの地図は、1:533.3f t. (6400m) と縮尺は大きいが、密度が满い。Rossの 地図と類似点が多いことから、茫大したと思われる。新たに、ヴォージニア・ストリートが 描かれている。(グラスゴー大学蔵)

34）現存するグラスゴーの地図の中で 5 番目に古い。それ以前に、グラスゴー全域を示すも のはなかった。

35）マッカーサーの地図にニュータウン計画が記されたもの（Yichell Library

36) E. Y. Galantay，1975，妮内英人訳「発生から見た都市のタイポロジー」 1984, pp. 43-45

37）文献[14]，pp51〜 52によると、1804 年の James Denho1mの測量地困を、1806 年に活 版制作者のGray \& Toddが生産したものである。

38）グラスゴー大学の社会学者であるPeter Fleming が、測量の会社を設立し地图の作成に あたった。

39) 文献 [17], pp. 37

40) 文献 $[8]$, pp. 56

41) J.W. Reps, The makeing of Urban America, 1965，pp.95-103、1662年に50エーカー の都市用地に、0.5エーカーにつき100〜200家族を收容するためのダリッドプランが作成さ れた

42）堀内氏の訳によると大陸会地地令となっている。法律法、元却される土地は6マ イル四方の区画に分割し配県するよう定めていた。それそれの区画は36の1マイル四方の街 区で成り立つ。

43）文献 [8]，註 28）の煀内氏鲃本 $\mathrm{p} 31-32$

44）立証できる砤かな記録はないが、ダラスゴーに残る地名に、アメリカの都市の名前も多 く、事実グラスゴーの発展はアメリカとの貿易を抜きにしてあり得なかった。このように深 く関わっていたアメリカの都市計画の利点を利用するのは自然である。

45) 文献[18], pp. 17

46) J.R. Kellett，Glasgow，pp12、James Craigが 2 度目のニュータウン䀦画関わってい た為、エジンバラとの関係は無視できない。

\section{考支献}

[1] Adams I.H. : The Marking of Urban Scotland, London: Croom Helm Ltd., 1978

[2] Baxter C., et. al : The City of Glasgow, Gloucester, UK: The British Publishing Co. Ltd. 1994

[3] Brooke M. and Bell B. : Insight Guides Glasgow, Hong Kong, APA P., 1996

[4] Doak A. M: and Young A. M. : Glasgow at glance, London: Robert Hale L., 1983

[5] Gibb A. : Glasgow The making of a city, Glasgow: Croom Helm Ltd., 1983

[6] Gomme A. and Walker D. : Architecture of Glasgow, London, L. Humphries Publishers, 1987 [7] Glasgow 1999 : Glasgow 1999 UK City of Architecture and Design, Glasgow Bid, 1997

[8] Guendoussi A. : The Grid- Hou Relevant Is It Today? Master Thesis in the Mackintosh School of Architecture, 1986

[9] Harper Collins Publishers : Glasgow Streetinder ATLAS, Edinburgh P. L, 1995

[10] Kellett J.R : Glasgow A concise History, London: Anthory Blond

[11] Massie A. : Gasgow portlaits of a city, London: Barrie \& Jenkins

[12] McKean C., et. al : Central Glasgow, Glasgow, Pillans \& Willson Ltd., 1993

[13] McLean J. : The City of Glasgow, Edinburgh, Colin Baxter, 1994

[14] Moore J.M. : The Maps of Glasgow, Glasgow, Glasgow University Library, 1996

[15] Pacione M. : Glasgow The Socio-spatial Development of the City, U.K., J. wiley \& Sons, 1995

[16] Strathclyde Regional Council: Glasgow City Center Rublic Realm, Glasgow, Gillespies, 1995

[17] Walker F.A : Glasgow's New Town, Read P. : Glasgow The Forning of the City, pp24-56, Edinburgh Edinburgh University Press Ltd., 1993

[18] Walker F.A. : The Glasgow Grid Markus T.A. : Otder in space and society, ppl55-199, Edinburgh: Mainstream Publishing Company Ltd., 1982

[19] Walker F.A. : The Emergence of the Grid: Later 18th-Century Urban Form in Glasgow, Brogden W.A : The Neo-classical Town Scottish Contributions to Urban Design Since 1750, pp 57-66, Edmburgh, The Rutland Press, 1996

[20] Williamson E., et. al : The building of Scotland Glasgow, London, Penguin G 1990

(1997年 9 月 8 日原稿受理, 1998年. 7 月 3 日採用決定) 